\title{
Soil and starter fertilizer and its effect on yield and protein composition of malting barley
}

\author{
A.H. Malik ${ }^{1,2 *}$ L. Holm ${ }^{1}$, E. Johansson ${ }^{1}$ \\ ${ }^{1}$ The Swedish University of Agricultural Sciences, Department of Agrosystems, Box 104, SE-230 53 Alnarp, Sweden. \\ ${ }^{2}$ Syngenta Seeds AB, Box 302, 26123 Landskrona, Sweden. *Correspondence author: Ali.Malik@syngenta.com
}

\begin{abstract}
Fertilizer application and growing locations are known to influence yield and protein concentration of malting barley. The aim of the present investigation was to evaluate the influence of soil and starter fertilizer on yield and protein composition in mature and maltedbarley. The cultivar Prestige was grown in two different soils (Lunnarp and Laxmans Âkarp) in combination with the use/non-use of starter fertilizer in climate chambers. Yield parameters, protein concentration and composition was measured. Effect of soil on plant emergence, yield and protein composition was significant while the effect of starter fertilizer was not. More nitrogen rich and low humus content soil (Lunnarp) resulted in higher grain yield and polymerization of proteins and lower protein concentration than the other soil. Combination of soil and starter fertilizer influenced protein composition in mature and malted barley. Breakdown of proteins were significantly higher at certain combination of soil and starter fertilizer than with other combinations. The Lunnarp soil combined with starter fertilizer was preferable to obtain high yield, low protein concentration and large grain size in mature grains. When breakdown of proteins at malting was taken into consideration as well, Lunnarp soil together with no starter fertilizer might be the best option.
\end{abstract}

Keywords: controlled conditions, Hordeum vulgare, location, mature barley, malted barley, optimized nutrients. 


\section{Abbreviations}

SDS-Sodium dodecyl sulphate; eSMP-SDS-extractable monomeric proteins; uSMP-SDS-unextractable monomeric proteins; TOTE -Total SDS-extractable proteins; TOTU-Total SDS-unextractable proteins; $\%$ LUPP-Percentage of large SDS-unextractable polymeric proteins in total large polymeric proteins; $\%$ TUPP-Percentage of SDS-unextractable polymeric proteins in total polymeric proteins; Monopol-Monomer/Polymers; SOM-Soil organic matter; DAS-days after sowing.

\section{Introduction}

Barley (Hordeum vulgare L.) is an important cereal crop grown worldwide not only for food and feed but it is also used as a raw material for the malting process to produce beer or other alcoholic beverages (Henry, 1989; Celus et al., 2006). The profitability of malting barley is influenced largely by the grain yield which in turn depends on a number of factors including differences in cultivar, farming conditions, soil and climate (Fathiet et al., 1997). In cool and moist regions early sowing is used for increasing the length of the growing season, thereby leading to increased grain yield (Barber, 1995). However, the early sowing often exposes the young seedlings to low soil temperature (Barber, 1995). Low soil temperature limits the mobility of nutrients in the soil and reduces the root growth, and thereby the availability of nutrients is limited, especially of those transported by diffusion, such as phosphorus (P) and potassium (K) (Barber, 1995). To overcome the nutrient deficiency that is often present at early sowing, the use of starter fertilizers is one option (Kristoffersen et al., 2004). Starter fertilizer is considered to enhance seed vigor and early growth, in periods of low nutrient status of soil, limited mobility of nutrients in soil, low soil temperature and slow root growth (Kristoffersenet et al., 2005). Effects of starter fertilizers on yield have primarily been evaluated in vegetables (Masauskas et al., 2008) but have also been shown positive for malting barley yield in Finland and Norway (Kleemola et al., 1998; Kristoffersen et al., 2005). However, excess of starter fertilizer application can also result in salt damage of the roots in the germinating seeds as has been shown e.g. in corn (Bates, 1971). Furthermore, soil initial nutrient levels and soil chemical composition are thought to affect the efficiency of starter fertilizers in barley (Riley, 1983; Kristoffersen . 2005). It has been found that the effect of starter fertilizer, on growth and yield of crop varies with different field locations (Stone, 2000). Influences of certain parameters such as growth and yield are difficult to judge from field experiments due to large environmental variations. Due to the mentioned variations, fertilizer effects on certain plant characters can preferably be studied under controlled conditions. To our knowledge, few studies (Hellgren and Nilsson, 2002) are available investigating the positive effects of starter fertilizer on plant growth and yield of malting barley in controlled conditions.

Both protein concentration and composition play an important role in determining the malt quality (Swanston et al., 1995; Wang et al., 2007). The protein concentration of malting barley (preferably 9.5$11.5 \%$ on dry basis, in most countries of the world) plays a crucial role in determining the quality of the malting barley (Gali and Brown, 2000; Palmer, 2000). Starter fertilizers may help the crop to accumulate more $\mathrm{N}$ in the grains, affecting indirectly the grain protein concentration (Masauskas et al., 2008). Availability of nutrients, especially $\mathrm{N}$ and $\mathrm{P}$, influences the protein and nucleic acid synthesis, and $\mathrm{K}$ influences protein synthesis, enzyme activation, osmo-regulation and root growth (Grant et al., 2001). It is also suggested that not only the protein concentration but also the protein composition may play an important role in determining the malt quality (Wang et al., 2007). 
The influence of starter fertilizers on the grain yield, protein concentration and composition of malting barley in controlled conditions has not been evaluated. Furthermore, only few studies have evaluated protein composition in mature barley grains and relations to malt quality (Molina-Cano et al., 2002; Wang et al., 2007). Studies about changes in protein composition during malting and how this is related to protein composition in mature grainare even scarcer.

Environmental variations, such as growing location and year are well known to influence grain yield and protein concentration in barley (Zhang et al., 2001) and also protein composition in wheat (Johansson, 2002). Recent findings have indicated the importance of soil parameters on yield, protein concentration/composition in wheat and barley (Wang et al., 2007; Andersson and Holm, 2011). Influences on grain yield and protein parameters by soil and soil-starter fertilizer interactions have been limitedly investigated both under field and controlled conditions.

Therefore, the aim of the present investigation was to evaluate the effect of soil and starter fertilizer on growth, yield, protein concentration and composition of malting barley, in controlled conditions. Further, the aim was to investigate whether protein concentration and composition in mature barley gra- ins influenced protein concentration and composition in malted barley grains.

\section{Materials and methods}

The spring malting barley cultivar Prestige with a germination rate of $96 \%$ was used. The plants were grown in controlled climatic chambers in the Biotron (manufactured by ÖKG-Grünbach, Austria and Skanska, Sweden) at the Swedish University of Agricultural Sciences (Alnarp, Sweden). A light intensity of $500 \mu \mathrm{mol} \mathrm{m}^{-1} \mathrm{~s}^{-1}$ was provided by fluorescent tubes (Sylvania Lumiance, type F 96 T12 VHO cold white 215W, Osram Sylvania, Mississauga, ON, Canada) installed in the ceiling of the climate chamber. Settings of weekly day and night lengths (taken from the calendar of sunrise and sunset), weekly average day and night temperatures and relative humidity in the climatic chamber are shown in Table 1. The temperature $\left({ }^{\circ} \mathrm{C}\right)$ settings in the Biotron were calculated as weekly means of the period April 10th to August 10th from a series of measurements of seven years (1987-1993) logged climate data from the small village Ädelholm $\left(55.66^{\circ} \mathrm{N}\right.$ and $\left.13.19^{\circ} \mathrm{E}\right)$, just outside Staffanstorp (Sweden), close to the sites where the soils were taken and where Nordic Sugar mill has an experimental site with a weather station.

Table 1. Climate used in the climate chambers when growing the malting barley cultivar Prestige.

\begin{tabular}{cccccc}
\hline Week & Sunrise & Sunset & MNT & MDT & RH \\
\hline 1 & $04: 40$ & $19: 20$ & 5 & 9 & 80 \\
2 & $04: 20$ & $19: 30$ & 5 & 9 & 80 \\
3 & $04: 00$ & $20: 20$ & 8 & 12 & 80 \\
4 & $03: 40$ & $20: 30$ & 10 & 13 & 80 \\
5 & $03: 20$ & $20: 50$ & 11 & 15 & 80 \\
6 & $03: 00$ & $21: 00$ & 12 & 15 & 80 \\
7 & $02: 50$ & $21: 20$ & 13 & 17 & 80 \\
8 & $02: 30$ & $21: 40$ & 13 & 15 & 80 \\
\hline
\end{tabular}




\begin{tabular}{cccccc}
\hline Week & Sunrise & Sunset & MNT & MDT & RH \\
\hline 9 & $02: 30$ & $21: 40$ & 14 & 18 & 80 \\
10 & $02: 20$ & $22: 00$ & 14 & 17 & 80 \\
11 & $02: 20$ & $22: 00$ & 15 & 18 & 70 \\
12 & $02: 20$ & $21: 50$ & 16 & 19 & 70 \\
13 & $02: 30$ & $21: 50$ & 17 & 20 & 70 \\
14 & $02: 40$ & $21: 40$ & 15 & 18 & 70 \\
15 & $02: 50$ & $21: 30$ & 16 & 28 & 70 \\
16 & $03: 10$ & $21: 10$ & 16 & 19 & 70 \\
17 & $03: 30$ & $21: 00$ & 16 & 19 & 70 \\
18 & $03: 40$ & $20: 50$ & 16 & 19 & 70 \\
\hline
\end{tabular}

$\mathrm{MNT}=$ Mean night temperature, $\mathrm{MDT}=$ Mean day temperature $\left({ }^{\circ} \mathrm{C}\right), \mathrm{RH}=$ relative humidity $(\%)$.

\subsection{Soil preparation}

In order to resemble field conditions, large containers, with a size of $80 \mathrm{~cm} \times 60 \mathrm{~cm} \times 40 \mathrm{~cm}$, were used in the experiment. The top soil used for growing the plant material in the containers was taken from two locations i.e. Laxmans $\AA$ karp $\left(55.73^{\circ} \mathrm{N}\right.$ and $\left.13.10^{\circ} \mathrm{E}\right)$ and Lunnarp $\left(55.54^{\circ} \mathrm{N}\right.$ and $\left.14.04^{\circ} \mathrm{E}\right)$. The two soils were selected from two representative fields where malting barley of good quality have previously been grown. The soil from both the locations was heated in the oven for $20 \mathrm{~h}$ at $105^{\circ} \mathrm{C}$ in order to kill all the pathogens and microorganisms that could affect the plant growth and development. The detailed information about the soil texture and content is given in Table 2 . After oven drying, the soil was sieved $(2 * 2 \mathrm{~cm})$ and blended to remove structure differences. In the bottom of every container $10 \mathrm{~cm}$ of perlite was placed as a water buffer. Above the perlite layer, $25 \mathrm{~cm}$ of soil was placed. Due to oven drying, all the water in the soils was removed. Throughout the experiment, the soil in each container was kept at a suitable humidity for the crop to avoid water stress. To ensure enough humidity in the soils, one of the containers in each climate chamber was placed on a weighing balance, by which the amount of water loss in the containers was assessed. This loss in amount of water was added to all the containers $\mathrm{n}$ this climate chamber every second or third day (depending on how much water was lost) with a bucket having a sprinkler tap on it. Thus, the same amount of water was added to both types of soil and to both treatments.

Table 2. The amount and percentage of different nutrients and soil texture of the used soils from Laxman karp and Lunnarp before and after drying.

\begin{tabular}{|c|c|c|c|c|}
\hline \multicolumn{5}{|c|}{ Soil from different locations } \\
\hline & \multicolumn{2}{|l|}{$\begin{array}{c}\text { Laxmans } \\
\text { Åkarp }\end{array}$} & \multicolumn{2}{|c|}{ Lunnarp } \\
\hline $\mathrm{mg} 100 \mathrm{~g}^{-1}$ & $\mathrm{BD}$ & $\mathrm{AD}$ & $\mathrm{BD}$ & $\mathrm{AD}$ \\
\hline P-Al & 10.1 & 12.1 & 3.90 & 4.80 \\
\hline $\mathrm{K}-\mathrm{Al}$ & 5.90 & 6.70 & 10.1 & 12.5 \\
\hline $\mathrm{Mg}-\mathrm{Al}$ & 8.90 & 7.30 & 15.5 & 13.7 \\
\hline $\mathrm{K} / \mathrm{Mg}$ & 0.70 & 0.90 & 0.60 & 0.90 \\
\hline $\mathrm{Ca}-\mathrm{Al}$ & 531 & 543 & 370 & 396 \\
\hline $\begin{array}{l}\text { Humus } \\
\text { Content (\%) }\end{array}$ & 4.00 & 4.10 & 3.10 & 3.10 \\
\hline $\begin{array}{l}\text { Clay } \\
\text { Content (\%) }\end{array}$ & 14.0 & 12.0 & 22.0 & 23.0 \\
\hline
\end{tabular}




\begin{tabular}{lcccc}
\hline \multicolumn{4}{c}{ Soil from different locations } \\
\hline & $\begin{array}{c}\text { Laxmans } \\
\text { Ákarp }\end{array}$ & \multicolumn{2}{c}{ Lunnarp } \\
\hline Silt (\%) & 33.0 & 33.0 & 35.0 & 34.2 \\
Sand (\%) & 49.0 & 50.9 & 39.9 & 39.7 \\
$\mathrm{NH}_{4}-\mathrm{N}\left(\mathrm{kg} \mathrm{ha}^{-1}\right)$ & 14.4 & 13.9 & 14.0 & 27.4 \\
$\mathrm{NO}_{3}-\mathrm{N}\left(\mathrm{kg} \mathrm{ha}^{-1}\right)$ & 14.1 & 11.6 & 7.60 & 4.80 \\
$\mathrm{~N}_{-} \mathrm{MIN}\left(\mathrm{kg} \mathrm{ha}^{-1}\right)$ & 28.5 & 25.5 & 21.6 & 32.2 \\
\hline
\end{tabular}

$\mathrm{BD}=$ before drying, $\mathrm{AD}=$ after drying.

\subsection{Replicates, treatments, sowing and fertilizer management}

The description about each treatment regarding soil and fertilizer management is given in Table 3. Two climate chambers and eight containers were used in the experiment, four containers in each chamber. Each climate chamber was considered as one replicate of the experiment. In each chamber, four different treatments were applied, one in each of the four containers. In treatment one and two, soil from Laxmans Åkarp was used. In the treatment three and four, soil from Lunnarp was used. The placement of the containers in the chambers was randomized. Hand sowing was done in all treatments by using a seed rate of 365 growing seeds $\mathrm{m}^{-2}$. After sowing, starter fertilizer $\left(8.016 \mathrm{~g}_{\text {container }}{ }^{-1}\right)$ was given to treatment one and three having soils from LaxmansÅkarp and Lunnarp, respectively. Park Complete (N-P-K: 12-5-15 manufactured by Yara AB, Landskrona, Sweden) was used starter fertilizer. After application of starter fertilizer in the seed row, a $2 \mathrm{~cm}$ layer of soil was spread by hand for making seedbed. The basal dose of $\mathrm{N}\left(100 \mathrm{~kg}\right.$ hectare $\left.^{-1}\right)$ was applied to all the four treatments including the ones which were given starter fertilizer. For basal dose of $\mathrm{N}$, the source used was Yara Mila (N-P-K: 24-4-5) manufactured by Yara AB, Landskrona, Sweden. After broad casting of the basal fertilizer application, a very thin layer $(1 \mathrm{~cm})$ of silver sand (Baskarps sand) was placed on the top layer of soil. The sand not only serves as an indicator of the water status of the soil but also for leveling out eventual evaporation differences.

Table 3. Description of treatments used for the growing of the spring malting barley cultivar Prestige in climate chambers.

\begin{tabular}{ccc}
\hline Treatment & Soil location & Starter fertilizer \\
\hline 1 & Laxmans Åkarp & Applied \\
2 & Laxmans Åkarp & Not applied \\
3 & Lunnarp & Applied \\
4 & Lunnarp & Not applied \\
\hline
\end{tabular}

\subsection{Harvesting and storage}

The spikes were harvested when the plants reached maturity at the Zadoks decimal code 92 (Zadoks et al., 1974). Grains from each treatment were weighed, lyophilized and weighed again, and thereafter grain water content was calculated. For breaking the dormancy of seeds in order to facilitate the malting, the grains were stored in a seed storage room for three months at $2^{\circ} \mathrm{C}$. Grain samples from the mature barley grains as well as from malted barley grains were milled in a Yellow Line commercial Blender (A 10, IKA- Werke, Staufen, Germany) for determination of amount and size distribution of polymeric proteins (ASPP) (Johansson et al., 2005; Malik et al., 2011). 


\subsection{Sampling and measurements of parameters related to plant growth and possible final yield}

Plant emergence was measured by counting the number of emerged seedlings in each container, at 14, 17, 20, 24 days after sowing (DAS) and finally at full emergence (30 DAS). For measuring of the plant height, number of tillers and length of top first, second and third leaf, fifteen plants were used in each container. To make the measurements as random as possible every tenth plant was selected. Plant height was measured with a measuring tape, from the soil to the top of the plant. After threshing, the grain yield (g) and thousand kernel weight $(\mathrm{g})$ for each combination of treatment was measured. Protein concentration (\%) (measured by NIR at Agrilab AB, Uppsala, Sweden), grain size $>2.5 \mathrm{~mm}(\%)$ and grain bulk density $\left(\mathrm{g} \mathrm{L}^{-1}\right)$ of each treatment was also measured.

\subsection{Malting}

Malting was carried out in the micro-malting plant at SLU, Alnarp, Sweden. This apparatus was designed by Danbrew consult Ltd, Copenhagen V, Denmark. Seed samples from each of the treatments and replicates together with one standard sample were used for malting. The weight of each sample was $80 \mathrm{~g}$. The malting was done according to Henry and McLean (1984) with some modification with the following three main steps. The samples were steeped for $6 \mathrm{~h}$ by immersion, followed by $11 \mathrm{~h}$ of dry period, with humidity maintained by passing air through a fine water spray. Temperature was maintained at $14.5^{\circ} \mathrm{C}$. By the end of steeping all the grains were fully hydrated and showing initial signs of germination - the formation of a tiny rootlet or "chit". Germination continued after the steeping for a further 4-5 days (96-120 h) with grain moisture maintained at $44-45 \%$. Temperature was maintained at $14.5^{\circ} \mathrm{C}$. The temperature in the kiln was increased uniformly from $40^{\circ} \mathrm{C}$ to $60^{\circ} \mathrm{C}$ over 11 $\mathrm{h}$ and held at $60^{\circ} \mathrm{C}$ for $2 \mathrm{~h}$. The temperature was then increased uniformly from $60^{\circ} \mathrm{C}$ to $80^{\circ} \mathrm{C}$ over $4 \mathrm{~h}$ and held at $80^{\circ} \mathrm{C}$ for a further $4 \mathrm{~h}$. The temperature was allowed to fall to $40^{\circ} \mathrm{C}$ over the next $1.5 \mathrm{~h}$. After a further $43 \mathrm{~h}$ the malted grains was reheated up till $60^{\circ} \mathrm{C}$, just before the rootlets were removed. The rootlets were removed manually by rubbing the seeds together with the hand in a plastic bag.

\subsection{Endosperm modification}

To check how much proteins have been modified in the endosperm during malting, the determination of endosperm modification was carried out according to Henry (1989). The endosperm modification was carried out before the kilning process was initialized.

\subsection{Protein analysis}

In a number of investigations, protein composition has been evaluated by the use of size exclusion high pressure liquid chromatography- SE-HPLC (Johansson et al., 2005, 2008). As we were interested to evaluate protein composition in malting barley and how the malting process influence the protein composition, SEHPLC was used with a two step extraction procedure according to Johansson et al. (2005) and Gupta et al. (1993). In the first step the SDS-soluble protein fractions (SDS-extractable proteins) were extracted while in the second step SDS-insoluble protein fractions (SDS-unextractable proteins) were extracted using sonication. Proteins were separated by SE-HPLC and detected at $210 \mathrm{~nm}$. SE-HPLC analyses was performed on a Waters (Milford, MA, USA) HPLC system using a BIOSEP SEC-4000 Phenomenex column. For the SE-HPLC analyses three replicates were analyzed from each container i.e. of each sample and replicate. The total area under the chromatogram was used to 
calculate TOTE $=$ total SDS-extractable proteins and TOTU $=$ total SDS-unextractable proteins. The SEHPLC chromatograms of both SDS-extractable and SDS-unextractable proteins were divided into two main parts which were further subdivided into two sections (Figure 1). The first part of the chromatogram representing polymeric proteins (PP), with a retention time interval 9.5-17 minutes, was divided into large PP (LPP) and small PP (SPP) (Malik et al., 2011). The second part of chromatogram corresponding to monomeric proteins (MP), with a retention time interval 17-29 minutes, was divided into large MP (LMP) and small MP (SMP). The amounts of SDS-extractable (e) and unextractable (u) small monomeric proteins (eSMP and USMP) were measured according to Johansson et al. (2005). Percentage of TUPP [SDS-unextractable $\mathrm{PP} /$ total (SDS-unextractable + SDS-extractable) PP $\mathrm{x}$ 100] was calculated according to Gupta et al. (1993). The PP part of the chromatogram containing the largest PP (L) was used to calculate \%LUPP according to Johansson et al. (2005). Monopol (Monomers/Polymers) [(SDS-extractable MP+SDS-unextractable MP)/(SDSextractable PP+SDS-unextractable PP)] was calculated according to Johansson et al. (2008).

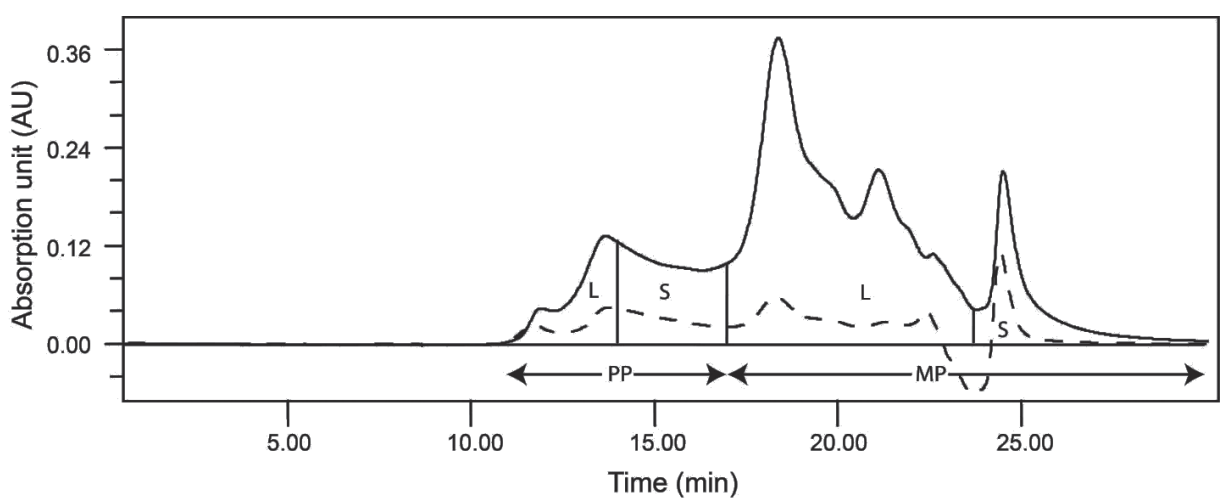

Figure 1. SE-HPLC chromatogram of SDS-extractable proteins $\left({ }_{(}\right.$) and SDS-unextractable proteins (---), respectively. The chromatogram was divided into two main parts comprising of polymeric proteins (PP) and monomeric proteins (MP), respectively. Each main part of the chromatograms was subdivided into two parts [designated as Large (L) and small (S)].

\subsection{Relative content of protein fraction}

For each of the protein fractions and treatments (for description see Table 3) the content was set to $100 \%$ in the mature grain and thereafter the relative content was calculated in the malted barley grains. Thus, a value above 100 indicates an increase while a value below 100 indicates a decrease of the protein fraction by the malting process.

\subsection{Statistical analysis}

MS Excel and the statistical package SAS (SAS, 2004) were used for figures and data analysis, respectively. Data evaluation was done by the Spearman rank correlation and analysis of variance procedures using SAS. 


\section{Results}

\subsection{Effect of treatments on plant growth}

Significantly higher number of plants had emerged, at 20 DAS, in soil from LaxmanÅkarp in comparison with soil from Lunnarp (Table 4). A significantly higher number of plants had emerged at 14 DAS when no starter fertilizer was applied as related to when starter fertilizer was applied (Table 4). However, the final number of plants at full emergence (30 DAS) was not influenced significantly, neither by the used soil nor by applied/not applied starter fertilizer dosage (Table 4). The treatments (combination of soil from different locations and applied/not applied starter fertilizer) did not significantly influence the number of emerged barley plants at different DAS (Table 4). Anthesis and maturity date did not differ significantly among treatments (results not shown).

Table 4. Mean values of plant emergence, length of the leaves and plant height at starter fertilizer dosage, two soil locations and four different treatments (for description see Table 3).

\begin{tabular}{|c|c|c|c|c|c|c|c|}
\hline \multicolumn{8}{|c|}{ Emerged plants } \\
\hline & $\begin{array}{c}14 \\
\text { DAS }\end{array}$ & $\begin{array}{c}20 \\
\text { DAS }\end{array}$ & $\begin{array}{c}30 \\
\text { DAS }\end{array}$ & $1^{\text {st }}$ leaf $(\mathrm{cm})$ & $2^{\text {nd }} l e a f(\mathrm{~cm})$ & $3^{\text {rd }}$ leaf $(\mathrm{cm})$ & Plant height $(\mathrm{cm})$ \\
\hline \multicolumn{8}{|c|}{ Starter Fertilizer } \\
\hline Applied & $72.2 b$ & $160.8 \mathrm{a}$ & $163.2 \mathrm{a}$ & $36.7 \mathrm{a}$ & $28.7 \mathrm{a}$ & $20.1 \mathrm{a}$ & $61.3 \mathrm{a}$ \\
\hline Not applied & $111.0 \mathrm{a}$ & $162.0 \mathrm{a}$ & $162.2 \mathrm{a}$ & $35.2 \mathrm{a}$ & $27.6 \mathrm{a}$ & $19.2 \mathrm{a}$ & $62.3 \mathrm{a}$ \\
\hline \multicolumn{8}{|l|}{ Soil locations } \\
\hline Laxmans Åkarp & $91.2 \mathrm{a}$ & $163.0 \mathrm{a}$ & $164.2 \mathrm{a}$ & $37.3 \mathrm{a}$ & $29.3 \mathrm{a}$ & $20.5 \mathrm{a}$ & $59.1 \mathrm{~b}$ \\
\hline Lunnarp & $92.0 \mathrm{a}$ & $159.8 \mathrm{~b}$ & $161.2 \mathrm{a}$ & $34.6 b$ & $27.0 \mathrm{~b}$ & $18.9 \mathrm{a}$ & $64.5 \mathrm{a}$ \\
\hline \multicolumn{8}{|l|}{ Treatments } \\
\hline Treatment 1 & $63.0 \mathrm{a}$ & $162.0 \mathrm{a}$ & $164.0 \mathrm{a}$ & $39.0 \mathrm{a}$ & $30.5 \mathrm{a}$ & $21.4 \mathrm{a}$ & $58.3 b$ \\
\hline Treatment 2 & $119.5 \mathrm{a}$ & $164.0 \mathrm{a}$ & $164.5 \mathrm{a}$ & $35.6 \mathrm{~b}$ & $28.1 \mathrm{ab}$ & $19.5 \mathrm{ab}$ & $59.9 \mathrm{~b}$ \\
\hline Treatment 3 & $81.5 \mathrm{a}$ & $159.5 \mathrm{a}$ & $162.5 \mathrm{a}$ & $34.4 \mathrm{~b}$ & $27.0 \mathrm{~b}$ & $18.9 \mathrm{~b}$ & $64.3 b$ \\
\hline Treatment 4 & $102.5 \mathrm{a}$ & $160.0 \mathrm{a}$ & $160.0 \mathrm{a}$ & $34.8 \mathrm{~b}$ & $27.0 \mathrm{~b}$ & $18.9 \mathrm{~b}$ & $64.8 \mathrm{a}$ \\
\hline
\end{tabular}

Means with the same letter within a column are not significantly different (LSD method $<0.05$ ). DAS= Days after sowing.

The soil from Laxmans $\AA$ karp resulted in significantly longer first and second leaves of the barley as compared to when soil from Lunnarp was used (Table 4). No significant differences were seen in the length of the third leaf when soils from different locations were used (Table 4). Applied/not applied starter fertilizer dosage did not influence the length of the first, second or third leaf significantly (Table 4). The first leaf from the top of the plant was significantly longer in treatment one (soil from Laxmans $\AA$ karp in combination with the application of starter fertilizer) in comparison with the other treatments (Table 4). Also, the second and third leaf from the top was long in treatment one although 
statistically similar with treatment two (soil from Laxmans Åkarp in combination with no application of starter fertilizer) in comparison with the other treatments (Table 4).

Plant height was not significantly affected by the applied/not applied starter fertilizer dosage (Table 4). Number of tillers per plant was not significantly influenced by the origin of soils, application of starter fertilizer dosage or treatments (results not shown). The significantly highest plants were obtained from treatment four (soil from Lunnarp in combination with no application of starter fertilizer) as related to when soil from LaxmanÅkarp and other treatments were used (Table 4).

\subsection{Effect of treatments on yield}

Soil originating from different locations affected the yield significantly (Table 5 ). The soil from Lunnarp resulted in significantly higher yield as compared to the soil from LaxmansÅkarp (Table 5). Applied/not applied starter fertilizer dosage did not significantly influence the grain yield (Table 5). Grain yield was not significantly influenced by the different treatments (Table 5).

\subsection{Effect of treatments on quality parameters}

Grains from plants grown on soil from LaxmansÅkarp were having higher protein concentration as compared to those grown on soil from Lunnarp (Table 5). Applied/not applied starter fertilizer dosage did not influence significantly the barley grain protein concentration at maturity (Table 5). Significantly the highest grain protein concentration were found, at maturity, when treatment one (soil from Laxmans Åkarp in combination with the application of starter fertilizer) was used in comparison with the other treatments (Table 5).
Table 5. Mean values of yield and quality parameters at maturity of spring malting barley at starter fertilizer dosage, two soil locations and four different treatments (for description see Table 3).

\begin{tabular}{lccc}
\hline & $\begin{array}{c}\text { Yield } \\
\left(\mathbf{g ~ m}^{-2}\right)\end{array}$ & $\begin{array}{c}\text { Protein } \\
\text { concentration } \\
\mathbf{( \% )}\end{array}$ & $\begin{array}{c}\text { Grain } \\
\mathbf{s i z e}>\mathbf{2 . 5} \\
\mathbf{m m} \mathbf{( \% )}\end{array}$ \\
\hline $\begin{array}{l}\text { Starter } \\
\text { Fertilizer }\end{array}$ & & & \\
Applied & $343.2 \mathrm{a}$ & $11.1 \mathrm{a}$ & $97.8 \mathrm{a}$ \\
Not applied & $354.6 \mathrm{a}$ & $10.7 \mathrm{a}$ & $98.6 \mathrm{a}$ \\
$\begin{array}{l}\text { Soil } \\
\text { locations }\end{array}$ & & & \\
Laxmans & $311.9 \mathrm{~b}$ & $11.3 \mathrm{a}$ & $96.8 \mathrm{~b}$ \\
Akarp & & $10.5 \mathrm{~b}$ & $99.6 \mathrm{a}$ \\
Lunnarp & $385.8 \mathrm{a}$ & & \\
Treatments & & $11.7 \mathrm{a}$ & $96.0 \mathrm{~b}$ \\
Treatment 1 & $296.9 \mathrm{a}$ & $10.9 \mathrm{~b}$ & $97.6 \mathrm{ab}$ \\
Treatment 2 & $326.9 \mathrm{a}$ & $10.5 \mathrm{~b}$ & $99.6 \mathrm{a}$ \\
Treatment 3 & $389.5 \mathrm{a}$ & $10.5 \mathrm{~b}$ & $99.6 \mathrm{a}$ \\
Treatment 4 & $382.2 \mathrm{a}$ & 10.5 \\
\hline
\end{tabular}

Means with the same letter within a column are not significantly different (LSD method $<0.05$ ).

Grains from the plants grown on soil from Lunnarp had significantly higher $\%$ of grains with a grain size $>2.5 \mathrm{~mm}$ as compared to those grown on soil from LaxmansÅkarp (Table 5). Applied/not applied starter fertilizer dosage did not significantly influence the $\%$ of grains with a grain size $>2.5 \mathrm{~mm}$ at maturity (Table $5)$. The $\%$ of grains with a grain size $>2.5 \mathrm{~mm}$ was significantly lower in grains from treatment one (soil from Laxmans Åarp in combination with the application of starter fertilizer) as compared to those from treatment three and four (soil from Lunnarp combined with and without the application of starter fertilizer) (Table 5). The grain bulk density was not influenced by applied/not applied starter fertilizer, soil from different locations or the treatments (result not shown). 
3.4 Effect of treatments and malting process on protein composition and content.

In mature barley grains, the soil from Lunnarp resulted in significantly higher \%LUPP and Monopol as related to the soil from LaxmansÅkarp (Table 6). Starter fertilizer application did not significantly influence the protein composition in the mature barley grains (Table
6). In mature grains of barley the amounts of TOTE were significantly higher in treatment one (soil from Laxmans Âkarp in combination with the application of starter fertilizer) as compared to treatments two and three (Table 6). Also, \%LUPP were significantly lower in treatment one as compared to treatment three and four and Monopol was significantly lower in treatment one as compared to the other treatments (Table 6).

Table 6. Mean values of the protein fractions in mature barley grains of the barley cultivar Prestige grown at starter fertilizer dosage, two soil from different locations and four different treatments (for description see Table 3).

\begin{tabular}{lccccccc}
\hline \multicolumn{1}{c}{ Source } & eSMP & uSMP & TOTE & TOTU & \% LUPP & \% TUPP & Monpol \\
\hline Starter Fertilizer & & & & & & & \\
Applied & $12.5 \mathrm{a}$ & $3.98 \mathrm{a}$ & $101 \mathrm{a}$ & $25.8 \mathrm{a}$ & $39.8 \mathrm{a}$ & $32.2 \mathrm{a}$ & $2.73 \mathrm{a}$ \\
Not applied & $12.4 \mathrm{a}$ & $4.08 \mathrm{a}$ & $97.6 \mathrm{a}$ & $25.7 \mathrm{a}$ & $42.2 \mathrm{a}$ & $33.5 \mathrm{a}$ & $2.78 \mathrm{a}$ \\
Soil locations & & & & & & & \\
Laxmans Åkarp & $12.2 \mathrm{a}$ & $4.06 \mathrm{a}$ & $101 \mathrm{a}$ & $26.7 \mathrm{a}$ & $38.0 \mathrm{~b}$ & $31.5 \mathrm{a}$ & $2.66 \mathrm{~b}$ \\
Lunnarp & $12.6 \mathrm{a}$ & $4.00 \mathrm{a}$ & $97.3 \mathrm{a}$ & $24.8 \mathrm{a}$ & $44.0 \mathrm{a}$ & $34.2 \mathrm{a}$ & $2.85 \mathrm{a}$ \\
Treatments & & & & & & & \\
Treatment 1 & $12.4 \mathrm{a}$ & $3.93 \mathrm{a}$ & $107 \mathrm{a}$ & $26.7 \mathrm{a}$ & $35.2 \mathrm{~b}$ & $29.6 \mathrm{a}$ & $2.59 \mathrm{c}$ \\
Treatment 2 & $12.1 \mathrm{a}$ & $4.19 \mathrm{a}$ & $95.2 \mathrm{~b}$ & $26.0 \mathrm{a}$ & $40.7 \mathrm{ab}$ & $33.4 \mathrm{a}$ & $2.73 \mathrm{~b}$ \\
Treatment 3 & $12.6 \mathrm{a}$ & $4.03 \mathrm{a}$ & $94.5 \mathrm{~b}$ & $24.9 \mathrm{a}$ & $44.4 \mathrm{a}$ & $34.7 \mathrm{a}$ & $2.87 \mathrm{a}$ \\
Treatment 4 & $12.6 \mathrm{a}$ & $3.96 \mathrm{a}$ & $100 \mathrm{ab}$ & $24.7 \mathrm{a}$ & $43.6 \mathrm{a}$ & $33.7 \mathrm{a}$ & $2.82 \mathrm{ab}$ \\
\hline
\end{tabular}

Means with the same letter within a column are not significantly different (LSD method $<0.05)$.

Differences in the amount of changes in the protein composition, during malting process, were found for the different treatments (Table 7). Treatment two (soil from Laxmans Åkarp combined with no application of starter fertilizer) increased significantly more the amount of eSMP as compared to treatment three (soil from Lunnarp combined with starter fertilizer), during malting process (Table 7). The amounts of TOTU, \%LUPP and \%TUPP decreased more in treatment two (soil from LaxmansÅkarp combined with no application of starter fertilizer) in comparison with the treatment one (soil from Laxmans ̊̊karp in combination with the application of starter fertilizer), during the malting process (Table 7). 
Table 7. Relative content of protein fractions after the malting process.

\begin{tabular}{lccccccc}
\hline & ESMP & uSMP & TOTE & TOTU & \%LUPP & \%TUPP & Monopol \\
\hline $\begin{array}{l}\text { Starter fertilizer } \\
\text { Applied }\end{array}$ & $112 \mathrm{~b}$ & $167 \mathrm{a}$ & $121 \mathrm{a}$ & $102 \mathrm{ab}$ & $58 \mathrm{~b}$ & $84 \mathrm{a}$ & $161 \mathrm{ab}$ \\
Not applied & $117 \mathrm{ab}$ & $169 \mathrm{a}$ & $124 \mathrm{a}$ & $98.1 \mathrm{ab}$ & $52 \mathrm{~b}$ & $76 \mathrm{ab}$ & $162 \mathrm{ab}$ \\
$\begin{array}{l}\text { Soil locations } \\
\text { Laxmans Akarp }\end{array}$ & $118 \mathrm{ab}$ & $168 \mathrm{a}$ & $123 \mathrm{a}$ & $102 \mathrm{ab}$ & $59 \mathrm{~b}$ & $82 \mathrm{a}$ & $177 \mathrm{a}$ \\
Lunnarp & $113 \mathrm{ab}$ & $168 \mathrm{a}$ & $122 \mathrm{a}$ & $101 \mathrm{ab}$ & $51 \mathrm{~b}$ & $77 \mathrm{ab}$ & $147 \mathrm{~b}$ \\
Treatments & $114 \mathrm{ab}$ & $171 \mathrm{a}$ & $119 \mathrm{a}$ & $106 \mathrm{a}$ & $81 \mathrm{a}$ & $85 \mathrm{a}$ & $178 \mathrm{a}$ \\
Treatment 1 & $121 \mathrm{a}$ & $166 \mathrm{a}$ & $128 \mathrm{a}$ & $91.0 \mathrm{~b}$ & $60 \mathrm{~b}$ & $63 \mathrm{~b}$ & $176 \mathrm{a}$ \\
Treatment 2 & $110 \mathrm{~b}$ & $163 \mathrm{a}$ & $124 \mathrm{a}$ & $97.0 \mathrm{ab}$ & $58 \mathrm{~b}$ & $63 \mathrm{~b}$ & $145 \mathrm{~b}$ \\
Treatment 3 & $114 \mathrm{ab}$ & $174 \mathrm{a}$ & $120 \mathrm{a}$ & $106 \mathrm{a}$ & $63 \mathrm{ab}$ & $69 \mathrm{ab}$ & $149 \mathrm{~b}$ \\
Treatment 4 & & & & & & &
\end{tabular}

Means with the same letter within a column are not significantly different (LSD method $<0.05$ ).

The amounts of TOTE in mature barley grains were negatively correlated to uSMP in malted barley grains (Table 8). Also, a positive correlation was seen between TOTE, in mature barley grains, and Mono- pol, in malted barley grains (Table 8). Percentage of \%LUPP and \%TUPP in mature barley grains were positively correlated with uSMP in malted barley grains (Table 8).

Table 8. Spearman rank correlations coefficients while comparing amount of different protein fractions (fract.) in mature and malted barley grains $(\mathrm{N}=24)$ of spring malting barley cultivar Prestige.

\begin{tabular}{lccccc}
\hline \multicolumn{5}{c}{ Protein fract. of malted barley grains } \\
\hline $\begin{array}{l}\text { Protein fract. of mature } \\
\text { barley grains }\end{array}$ & eSMP & uSMP & \%LUPP & \%TUPP & Monopol \\
\hline TOTE & 0.07 & $-0.54^{* *}$ & 0.36 & 0.34 & $0.45^{*}$ \\
TOTU & -0.15 & 0.38 & -0.18 & -0.19 & -0.20 \\
\%LUPP & -0.20 & $0.57^{* * *}$ & $-0.47 *$ & $-0.45^{*}$ & $-0.43^{*}$ \\
$\%$ TUPP & -0.22 & $0.59 * * *$ & $-0.42 *$ & -0.40 & $-0.49^{*}$ \\
\hline
\end{tabular}

$*, * *, * * *=$ Significant at $p<0.05,0.01,0.005$.

\section{Discussions}

In the present investigation soil originated from different locations was of major importance for emergence, yield and protein composition of malting barley. Also, combination of treatments i.e. soil from different locations combined with differences in application of starter fertilizer, affected plant growth, yield and protein composition and concentration in the present investigation. However, in contrary to earlier investigations on vegetables (Stone, 2000) and barley (Hellgren and Nilsson, 2002; Kristoffersen et al., 2005), the use of starter fertilizer did not show a general and independent influence on plant growth, development and protein composition in barley seeds in the present investigation. 
As can be seen from Table 2, the two soils used in our study differed in a range of parameters. One obvious difference between the two soils were also their reaction to the drying procedure, resulting in an increase content of $\mathrm{NH}_{4}-\mathrm{N}$ and N-MIN together with a decrease in content of $\mathrm{NO}_{3}-\mathrm{N}$ in the soil from Lunnarp while the $\mathrm{N}$ contents of soil from LaxmansÅkarp remained rather stable. The total nitrogen content in the soil from Lunnarp was thereby higher after drying than the content in the soil from Laxmans ̊karp which might be part of explanation for the higher yield in malting barley grown on the soil from Lunnarp. However, the differences in $\mathrm{N}$ content between the two soils was around $7 \mathrm{~kg} \mathrm{ha}^{-1}$ (Table 2), which is a negligible sum, especially as a basal dose of $\mathrm{N}$ of $100 \mathrm{~kg} \mathrm{ha}^{-1}$ was applied. The soil from the location that resulted in high grain yield (Lunnarp) was lower in soil organic matter (SOM) or humus content than soil from the other location (LaxmansÅkarp). Also, the soil from the Lunnarp location had higher clay (\%) and silt (\%) content than the soil from Laxmans Akarp. SOM is important for macro and micronutrients supply as well as for moisture availability and buffer capacity. It also affects soil aggregate stability and soil structure in general (Riley, 1983). Thus, the variation between the two soils in SOM and clay/sand might be the main reason explaining differences in yield of malting barley in the present experiment. One might speculate that especially during field conditions, higher SOM and clay content might result in higher moisture availability and buffer holding capacity. However, after the pre-treatment of the soils and the equal additions of water and avoidance of drought in the soils, variation in moisture availability between the two used soils seems less likely. Another explanation might be variation between the two soils in amount of nutrients available at various times during crop development. It is well known that early $\mathrm{N}$ availability increase biomass of the plant at early development stages which is also related to increased yield (Malik, 2012). Also, N availability has been found an important parameter for protein composition in wheat (Johansson et al., 2005). However, impact of various parameters is related to the temperature during crop cultivation (Malik et al., 2013). To be able to fully explain the impact of various soil parameters on yield and protein composition, additional screening of soils, soil parameters, yield and protein factors are needed.

Thus, starter fertilizer seemed to influence the results more when applied to the soil from LaxmanÅkarp, than when applied to the soil from Lunnarp. TOTE is known to correlate positively with protein concentration in wheat (Johansson et al., 2003). If the amount of TOTE is related to high protein concentration also in malting barley, high amounts might lead to a decrease in malt quality (Palmer, 2000). Therefore, soil initial fertility level should be considered in scheduling the fertilizer dosage for malting barley production. This consideration of fertilizer management may help in attaining desired protein concentration for beer production (Gali and Brown, 2000). Soil from Lunnarp in combination, with starter fertilizerand without starter fertilizer, has resulted in grains with the highest amount of \%LUPP and Monopol. In wheat, a short grain filling period both determined genetically (Malik et al., 2011) and environmentally (Johansson et al., 2005; 2008) has been shown to correlate to a high \%LUPP (Large UPP). If the differences in treatments have resulted in various times for grain filling period, was not investigated in this study. 
The most relevant finding from the present investigation was that the choice of soil and the use of starter fertilizer have influenced the breakdown patterns of proteins during malting. Thus, the effect of treatments seems more remarkable for protein composition after malting than in mature barley. Generally, high protein concentration in the mature barley grain (TOTE; Treatment 1 and 4), resulted in high breakdown rate of easily extractable proteins, resulting in a low decrease in \%LUPP and \%TUPP and an increase in TOTE and/or TOTU, as was also described in Malik (2012). The importance of not just investigating protein composition in mature grains but also during processing, has been emphasized recently also in wheat during mixing, where protein composition was not straightly correlated with protein composition in the grain (Hussain et al., 2012). Variation in breakdown of proteins depending on treatment during cultivation has not been reported previously, to our knowledge. One might speculate that a higher breakdown rate will result in higher amounts of free amino acids and peptides within the malted barley. The smaller protein related molecules can easily be transferred into the ready beer and influence the beer quality. These issues need more investigations before final conclusion can be drawn as to how cultivation practices influence the beer quality on a protein related molecular scale.

The small protein molecules found in the SMP fractions besides peptides and amino acids are albumins (Johansson et al., 2008). Thus barley albumins such as z-proteins and lipid transfer proteins (LTP) are supposed to be found in the SMP fraction. Z-proteins are considered good for foam stability and LTP are considered important for foam formation (Sørensen $e t$ al., 1993). In the present investigation, no differences in SMP were found, in mature barley grains, among the used treatments. More investigations are needed, especially of the SMP fractions, in order to understand how protein composition is influencing beer quality.

\section{Conclusions}

Soil from different locations was found to play a major role in influencing the early growth stages and yield of spring malting barley. In the present study, the soil N-content was positively related to yield and polymerization of the proteins, while negatively related to protein concentration. In certain soils, starter fertilizer can contribute to establish the later growth (plant height, leaf length) of a crop, but also to increase grain protein concentration. For achieving high yields, desired protein concentration and composition, combination of specific soil location with starter fertilizer are of utmost importance. In the present investigation, treatment 3 (soil from Lunnarp with starter fertilizer application) seemed preferable for mature barley with high yield, low protein concentration, large grain size and low TOTE. However, as large breakdown of proteins at maturity might be negative, treatment 4 (soil from Lunnarp with no starter fertilizer application) might be more desirable.

\section{Acknowledgements}

The SL-stiftelsen, Partnerskap (Alnarp, Sweden) and the Higher Education Commission (Islamabad, Pakis$\tan$ ) are deeply acknowledged for providing funds for the research project and $\mathrm{PhD}$ education. 


\section{References}

Andersson, A., Holm, L .2011.Effects of mild temperature stress on grain quality and root and straw nitrogen concentration in malting barley cultivars. J.Agron. Crop Sci. 197, 466-476.

Barber, S.A. 1995. Soil nutrient bioavailability: A mechanistic approach. John Wiley \& Sons, New York, 414 p.

Bates, T.E. 1971. Response of corn to small amounts of fertilizer placed with the seed: II. Summary of 22 field trials.Agron. J. 63, 369-371.

Celus, I., Brijs, K., Delcour, J.A. 2006.The effects of malting and mashing on barley protein extractability. J.Cereal Sci .442, 203-211.

Fathi, G., McDonald, G.K., Lance, R.C.M. 1997. Effects of post-anthesis water stress on the yield and grain protein concentration of barley grown at two levels of nitrogen. Aust. J. Agric. Res. 48, 67-80

Gali, V.J., Brown, C.G. 2000.Assisting decisionmaking in Queensland barley production through chance constrained programming. Aust. J. Agric. Res. 442, 269-287.

Grant, C.A., Flaten, D.N., Tomasiewich, D.J., Shepard, S.C. 2001. The importance of early season phosphorus nutrition. Can. J. P. Sci. 81, 17-19.

Gupta, R.B., Khan, K., MacRitchie, F. 1993.Biochemical basis of flour properties in bread wheats. I. Effects of variation in the quantity and size distribution of polymeric protein. J. Cereal Sci. 18, 23-41.

Hellgren, O., Nilsson, G. 2002. Kan optimala näringsproportioner för korn fastställas och gynna tidig tillväxt? Forskningsrapport Alnarp, Biotronen, Sveriges lantbruksuniversitet. (In Swedish)

Henry, R.J. 1989.Factors influencing the rate of modification of barleys during malting. J. Cereal Sci. 10,1, 51-59.
Henry, R.J., McLean, B.T. 1984 .Effect of sample size on the micro-malting of barley. J. Sci. Food Agri. $35,7,767-772$.

Hussain, A., Larsson, H., Kuktaite, R., PrietoLinde, M.L., Johansson, E. 2012. Towards the understanding of bread-making quality in organically grown wheat: Dough mixing behaviour, protein polymerisation and structural properties. J. Cereal Sci. 56, 659-666.

Johansson, E. 2002. Effect of two wheat genotypes and Swedish environment on falling number, amylase activities, and protein concentration and composition .Euphytica $126,1,143-149$.

Johansson, E., Prieto-Linde, M. L., Gissén, C. 2008. Influences of weather, cultivar and fertilizer rate on grain protein polymer accumulation in fieldgrown winter wheat, and relations to grain water content and falling number. J. Sci. Food Agri. 88, 11, 2011-2018.

Johansson, E., Kuktaite, R., Andersson, A., Prieto-Linde, M.L. 2005.Protein polymer buildup during wheat grain development: influences of temperature and nitrogen timing. J. Sci. Food Agri. 85,473-479.

Johansson, E., Prieto-Linde, M.L., Svensson, G., Jönsson, J.Ö. 2003.Influences of cultivar, cultivation year and fertilizer rate on amount of protein groups and amount and size distribution of mono- and polymeric proteins in wheat. J. Agri. Sci. 140, 275-284.

Kleemola, J., Järvi, A.,Kkauppila, R. 1998. Placing nutrients with seed. Kungliga skogs- och lantbruksakademiens tidskrift. 137, 93-98.

Kristoffersen, A.Ø., Bakkegard, M., Hoel, B.O. 2005.Starter fertilizer to spring barley and spring wheat in south-east Norway: Effects on growth and nutrient uptake. Acta Agri.Scand,Section B, Soil Plant Sci. 55,4, 252 - 263. 
Kristoffersen, A.Ø., Bakkegard, M., Hoel, B.O., Tandsæther, H. 2004 .Startgjødslingtil korn- oppsummering av 6 år med forsøk. In: M. Bakkegard (ed).Jord- og plantekultur. Planteforsk, Apelsvoll, pp:138-149. (In Norwegian.)

Malik, A.H. 2012.Governinig grain protein concentration and composition in wheat and barley.Thesis.ActaUniversitatisagriculturae Sueciae 2012:55.The Swedish University of Agricultural Sciences.Sweden

Malik, A. H., Prieto-Linde, M.L., Kuktaite, R., Andersson, A., Johansson, E. 2011. Individual and interactive effects of cultivar maturation time, nitrogen regime and temperature level on accumulation of wheat grain proteins. J. Sci. Food Agri. 91, 2192-2200.

Malik, A. H., Kuktaite, R., Johansson, E. 2013. Accumulation of proteins in the wheat grain: the combined effect of genetic and environmental factors and their relation to bread-making quality. J. Cereal Sci. doi:10.1016/j.jcs.2012.09.017

Masauskas, V., Masauskiene, A., Repsiene, R., Skuodiene, R., Braziene, Z., Peltonen, J. 2008. Phosphorus seed coating as starter fertilization for spring malting barley. Acta Agri.Scand,Section B. Soil Plant Sci. 582, 124-131.

Molina-Cano, J.L., Sopena, A., Polo, J.P., Bergareche, C., Moralejo, M.A., Swanston, J.S., Glidewell, S.M. 2002. Relationships between barley hordeins and malting quality in a mutant of cv. Triumph. II. Genetic and environmental effects on water uptake. J. Cereal Sci. 36, 39-50.

Palmer, G H. 2000. Malt performance is more related to inhomogeneity of protein and $\beta$-glucan breakdown than to standard malt analyses. J.Inst. Brew.106,3, 189-192.

Riley, H. 1983. Soil physical properties of clay and silt soils. Effects of organic matter content and soil conditioners. Forskningogforsokilandbruket. 34, 155-165.

SAS. 2004. SAS ${ }^{\circledR}$ 9.1.2 qualification tools user's guide. NC, USA: SAS Institute INC.

Sørensen, S.B., Bech, L.M., Muldbjerg, M., Beenfeldt, T., Breddam, K. 1993. Barley lipid transfer protein 1 is involved in beer foam formation. MBAA Tech.Quart. 30, 136-145.

Stone, D.A. 2000. The effects of starter fertilizers on the growth and nitrogen use efficiency of onion and lettuce. Soil Use Manag.16, 42-48.

Swanston, J.S., Ellis,R.P., Rubio,A., Perez-Vendrel, A., Molina-Cano,J.L. 1995.Differences in malting performance between barleys grown in Spain and Scotland. J.Inst. Brew.101, 261-265.

Wang, J M., Chen, C.H., Dai, F., Wu, F.B., Yang, J.M., Zhang, G.P. 2007. Protein fractions in barley grains as affected by some agronomic factors and their relationships to malt quality.Cereal.Res. Comm. 35,1, 129-140.

Zadoks, J.C., Chang, T T., Konzak, C F. 1974. A decimal code for the growth stages of cereals. Weed Res.14, 6, 415-421.

Zhang, G., Chen, J., Wang, J., Ding, S. 2001. Cultivar and Environmental Effects on $(1 \rightarrow 3,1 \rightarrow 4)$ $\beta$-D-Glucan and Protein Content in Malting Barley. J.Cereal Sci. 34 ,3, 295-301. 
